\title{
Coleridge, Johnson, and Shakespeare: A Critical Drama in Five Acts
}

\section{Citation}

Engell, James. 1998. Coleridge, Johnson, and Shakespeare: A critical drama in five acts. Romanticism 4(1): 22-39.

\section{Published Version}

http://www.eupjournals.com/

\section{Permanent link}

http://nrs.harvard.edu/urn-3:HUL.InstRepos:3354158

\section{Terms of Use}

This article was downloaded from Harvard University's DASH repository, and is made available under the terms and conditions applicable to Other Posted Material, as set forth at http:// nrs.harvard.edu/urn-3:HUL.InstRepos:dash.current.terms-of-use\#LAA

\section{Share Your Story}

The Harvard community has made this article openly available.

Please share how this access benefits you. Submit a story.

\section{Accessibility}


JAMES ENGELL

\section{Coleridge, Johnson, and Shakespeare, A Critical Drama in Five Acts}

Nature, who seems to be fond of trios, has given us three dogmatists... - Johnson, Coleridge, and Carlyle. Each was an oracle in his way, but unfortunately oracles are fallible to their descendants. . . Each oracle denies his predecessor, each magician breaks the wand of the one who went before him.

Oliver Wendell Holmes, One Hundred Days in Europe (1887)

\section{PROLOGUE}

Coleridge studied Johnson's entire Shakespearean criticism, chiefly in the 21 volume octavo 'variorum' 1803 edition of Isaac Reed, which contains Johnson's Preface and his commentary to all the plays, as well as the notes of Steevens and Malone, the Prefaces by Pope, Rowe, Theobald, Hanmer, Capell, Warburton, and Steevens, along with Farmer's essay on Shakespeare's learning, and Malone's study of the English stage and his chronology of Shakespeare's plays. Consulting it at the lectern, especially in his 1811-12 series, Coleridge used this edition extensively. It was his avowed, publicly advertised purpose and - in the course of the lectures his repeated practice to comment on Pope's and Johnson's Prefaces and explicitly to address Johnson's annotations. Coleridge criticized, even vilified, Johnson's approach, calling Johnson one of the Frog Critics, those 'frogs croaking in a ditch' until light is cast on them and they suddenly grow silent. In notes at hand for the lectures, Coleridge writes, 'Johnson $=$ the Frog-Critic - How nimbly it leaps - how excellently it swims - only the fore-legs (it must be admitted) are too long \& the hind ones too short - ). ${ }^{1}$

\section{ACT I. COMPREHENDING SHAKESPEARE}

Coleridge lumps Johnson with other critics, none of whom, he says, understand Shakespeare's unique dramatic energy, the principles on which he wrote, or his language (LI, II, p. 514). Instead, they treat Shakespeare as a child of nature. J.P. Collier, who made the most extensive record of the 
lectures, noted: 'It is rather humiliating to find that since Shakespeare's time none of our Critics seem to enter into his peculiarities. Coleridge would not dwell on this point because he intended to devote a lecture more immediately to the prefaces of Pope and Johnson . . . the moderns in their prefaces praise him as a great genius but when they come to their notes . . they treat him like a Schoolboy... They had maintained that Shakespeare was an irregular poet that he was now above all praise and now if possible below contempt \& they reconciled it by saying that he wrote for the mob' (LL, I, p. 353; cf. II, p. 515). In earlier lectures Coleridge claims, 'In the opinion of such persons, Shakespeare was an ignorant man, a child of nature, a wild genius, a strange medley - at least as the most admired critics, such as DrJohnson, thought'; ' . . it was a . . refuge, to talk of Shakespeare as a sort of beautiful Lusus Naturae, a delightful Monster - wild indeed, without taste or Judgment' (LL, I, pp. 274-75, p. 79 and nn.). While Hugh Blair and others say this, Johnson never does. He does, however, observe that Shakespeare was not learned and compares the garden of a 'correct and regular writer' to Shakespeare's 'forest, in which oaks extend their branches, and pines tower in the air, interspersed sometimes with weeds and brambles.' And Johnson offers, in a complementary way, "Whether Shakespeare knew the unities, and rejected them by design, or deviated from them by happy ignorance, it is, I think, impossible to decide, and useless to enquire' (p. 79). But he does not say what Coleridge ascribes to him. Johnson's image of a forest rather than a regular 'garden accurately formed and diligently planted' apparently so piqued Coleridge that Coleridge digressed about the superiority of the natural in Shakespeare, seeing in it a unity or 'Homogeneity... of interest' characterizing each play, which he then illustrates with a parallel image: 'Yet instead of Unity of Action I should great [ly] prefer the more appropriate tho' scholastic and uncouth words - Homogeneity, proportionateness and totality of Interest ... Whence the Harmony that strikes us in the wildest natural landscapes? In the relative shapes of rocks, the harmony of colors in the Heath, Ferns, and Lichens, the Leaves of the Beech, and Oak, the stems and rich choc[ol]ate-brown Branches of the Birch, and other mountain Trees, varying from varying Autumn to returning Spring - compared with the visual effect from the greater number of artificial Plantations? - The former are effected by a single energy, modified ab intra in each component part-. Now as this is the particular excellence of the Shakespearian Dramas generally, so is it especially characteristic of the Romeo and Juliet' (LL, II, p. 362). Right down to the trees, this comment, ironically, champions the view of Shakespeare as a natural poet, a poet of organic relations (if not a child of nature), rather than a poet of artificial regularity. It partially vindicates Johnson's observations; it rejects yet recalls 


\section{ROMANTICISM}

those who praise Shakespeare's 'wild' nature. But Coleridge in his Shakespearean forest will suffer no 'mass of meaner minerals' (p. 84) and no weeds or brambles, rather ferns and lichens. Johnson and others, he believes, ignore the judgment of Shakespeare that makes each drama a whole with unity of interest, in which are displayed not wild genius yoked to errant judgment, but judgment and genius each of the highest mark. In Biographia Coleridge continues to protest that Shakespeare is 'no mere child of nature; no automaton of genius'. ${ }^{3}$ Yet Johnson's criticism fundamentally concurs with these statements, as does that of others in Johnson's day, including Alexander Gerard's. In the 'Life of Roscommon', Johnson says, 'It is ridiculous to oppose judgment to imagination; for it does not appear that men have necessarily less of one as they have more of the other'. Coleridge repeats this precisely in his Notebooks, and later it appears in Anima Poetae: 'Great Injury has resulted from the supposed Incompatibility of . . . Judgment with Imagination, \& Taste' (see BL, II, pp. 26-7 n.3). In the Preface, Johnson states that his arguments, he hopes, will persuade readers 'to give their approbation to the judgment of Shakespeare', an aim carefully considered, since it comes after his own warning that 'approbation, though long continued, may yet be only the approbation of prejudice or fashion' (pp. 81, 61). Finally, we have Coleridge's own remark, almost against himself. While he asserts that Shakespeare 'never wrote anything that he knew would degrade himself', he prefaces this by admitting, 'Careless he might be or he might write at a time when his better genius did not attend him' (LL, I, pp. 353).

Coleridge states that earlier critics, including Johnson, drag down Shakespeare's reputation; if they at times place him higher than other writers they negate this by alternately placing him lower, too. For Coleridge, Shakespeare has no rival; he brooks no comparison: 'Shakespear can be complimented only by comparison with himself: all other eulogies are either heterogeneous, (ex. gr. in relation to Milton, Spencer, \&c) or flat truisms (ex. gr. to prefer him to Racine, Corneille, or even his own immediate Successors, Fletcher, Massinger \&c.).' In this instance, Coleridge compares Anthony and Cleopatra to Shakespeare's other tragedies. ${ }^{4}$ While Johnson does not precisely say this, he does say something similar: 'It will not easily be imagined how much Shakespeare excells in accommodating his sentiments to real life, but by comparing him with other authours. It was observed of the ancient schools of declamation, that the more diligently they were frequented, the more was the student disqualified for the world, because he found nothing there which he should ever meet in any other place. The same remark may be applied to every stage but that of Shakespeare' (p. 63). In fitting sentiments and language to real life, 
Shakespeare is incomparable. If Johnson does not see all of Shakespeare's qualities in that light, he sees them in a combination that is superior and unique. But that Johnson criticizes any quality as 'contemptible', or with similar epithets, or calls Shakespeare irregular, irritates Coleridge. And Coleridge certainly disagrees with comments such as, 'The plots are often so loosely formed, that a very slight consideration may improve them, and so carelessly pursued, that he seems not always fully to comprehend his own design' (p. 71).

Because of a special harmony in Shakespeare's plays, Coleridge sees in each an organic unity, a wholeness drawing together each part so that they are 'characteristic throughout' ( $L L, I$, p. 564). He associates Johnson with critics concerned chiefly with parts, with individual characters or scenes. Johnson says, as Coleridge's editor notes, that 'He has scenes of undoubted and perpetual excellence, but perhaps not one play, which, if it were now exhibited as the work of a contemporary writer, would be heard to the conclusion' (p. 91; see LL, I, p. lxviii and n.). But we should note that Johnson qualifies his remark by inserting 'as the work of a contemporary writer'. And while Johnson does not see the dramas in light of a total organic unity, he remarks, with regard to tragedy, that 'others please us by particular speeches, but he always makes us anxious for the event, and has perhaps excelled all but Homer in securing the first purpose of a writer, by exciting restless and unquenchable curiosity and compelling him that reads his work to read it through' (p. 83). From Johnson this is the highest praise. ${ }^{5}$

In a lecture on Milton, Coleridge calls Johnson 'a fellow' and is hissed. Coleridge apologizes, saying 'It is in the nature of Evil to beget Evil - and the indignation we feel at injustice makes us commit the same' ( $\mathrm{LL}, \mathrm{I}$, p. 411). The 'Life of Milton' may be the most unfair Johnson wrote, yet we can reflect that Coleridge, perhaps brought up short by the only hiss recorded in his approximately 100 lectures, admits that he likewise is being unfair to Johnson. Curiously, even Coleridge's comments on Johnson's style, generally negative, admit a variant of the phrase - 'can please many' from Johnson's Preface: 'Johnson's style has pleased many from the very fault of being perpetually translateable; he creates an impression of cleverness by never saying any thing in a common way' (LL, II, p. 237).

In textual commentary and annotation, Coleridge can diverge from and quarrel with Johnson, but agrees with him often, too. On Polonius, Coleridge says 'that his recollections of past life were of wisdom, and shewed a knowledge of human nature, whilst what immediately passed before him, and escaped from him, was emblematical of weakness' (LL, I, p. 520). As T.M. Raysor pointed out, this owes something to Johnson's note that Polonius 'is knowing in retrospect, and ignorant in foresight'. In the 
exchange between Hamlet and Ophelia, where Hamlet offers 'Do you think I meant country matters?' Johnson suggests changing this to country manners and glosses it as, 'Do you imagine that I meant to sit in your lap, with such rough gallantry as clowns use to their lasses?' (Works, VIII, p. 985); Coleridge, perhaps following Malone, is more astute: 'I am afraid that a painfully gross play on syllables was intended' (CM, COPY D). Coleridge mistakenly criticizes Johnson for holding that Shakespeare had no motive for sending Hamlet to England other than following the fiction from which he took the play. Johnson says no such thing. Moreover, in the Preface, he claims Shakespeare 'always makes nature predominate over accident' (p. 65). However, Coleridge then gives an account of this episode in relation to Hamlet's character entirely more perceptive than Johnson's (LL, I, pp. 389-90; II, pp. 540).

Johnson believes that when Hamlet decides against killing Claudius while the king prays, it is too horrible and calculated: the young Dane desires not only the death but the damnation of his uncle. Coleridge objects to the 'horror-striking fiendishness' implied by Johnson's interpretation and sees Hamlet's hesitation rather as one more instance of the motive mongering and excuse gathering that define Hamlet's inability to act his 'reluctance \& procrastination' - his talent to equivocate (CM COPY D; LL, I, p. 389). This constitutes an interesting difference of opinion, pointing to Johnson's religious scruples and Coleridge's psychological insight. (For Coleridge's own use of the new term 'psychological,' see LL, I, p. lxxv.) Johnson and Coleridge also present divergent readings of the character of Richard II (LL, I, pp. 381-82). But, when confronted with Dryden's remark that Shakespeare killed off Mercutio because Shakespeare's exhausted genius had to get him out of the way, Coleridge rejoices to concur that 'indeed Dr Johnson had fully replied' that not some whim but, as Johnson puts it, 'the construction of the play' fixed 'the time allotted' to Mercutio (LL, I, p. 307 and n.8; see II, p. 491). Coleridge and Johnson agree on readings and interpretations of several other passages, the two alone facing all other editors and critics.

Coleridge treats other commentators - Pope, Warburton, Theobald more roughly. In one passage, because of a 'style so peculiarly vital and organic', Coleridge sees Shakespeare at the mercy of 'The absurdity of Warburton's Gloss'. When Warburton and Theobald change 'Philip? Sparrow!' to 'Philip! - spare me!' Coleridge righteously and rightfully lets go: 'O true Warburton! and the Sancta Simplicitas of honest dull Theobald's faith in him! - Nothing can be more lively or characteristic than Philip? Sparrow!' Warburton, remarks Coleridge, has 'deathified Sparrow into Spare me'. And then this outburst: 'O Theobald! what a Commentator wast 
thou, when thou would'st affect to understand Shakespear! - instead of collating his Text. The meaning here was too deep for a Line 10 fold the Length of thine to fathom! -.6

\section{ACT II. BEAUTIES AND FAULTS: SHAKESPEARE'S MORALITY}

From Coleridge's objection to any negative criticism of Shakespeare flows his objection to the balancing of merits and faults found in Johnson's (and most earlier) criticism. ${ }^{7}$ Since Johnson says the chief fault of Shakespeare, which 'the barbarity of his age cannot extenuate', is his lack of explicit morality - he 'sacrifices virtue to convenience' - Coleridge makes this the focus of his charge. In a notebook entry (July 1810) he likely used for his lectures, Coleridge attacks the 'Johnsonian Antithesis of Black \& White' and continues, 'One would suppose from Johnson's Preface that Sh. was a pie-bald Poet - \& that he, the Critic, was standing by, in the worthy employment of counting \& pointing out, black spot against white . . Further, illustrate this damnable rage of judging by the faults, imprimis, instead as of yore by his excellences ...' (LL, I, p. 394). Coleridge says in one lecture, immediately after mentioning Johnson's name, that critics have made Shakespeare into 'a Chessboard, with here a white square, there a black square. Here Shakespeare was below contempt - there he rose above all praise . . . They, in short, had made him here white $\&$ black, and the only wonder was that after so much trampling they had not made him black $\&$ blue' (LL, I, p. 275).

In his 1811-12 series, Coleridge devotes a full lecture and part of another to Johnson's Preface, taking Johnson to task for weighing faults against virtues. Yet, four years later, Coleridge does the same thing in his long critique of Wordsworth's poetry, chapter 22 of Biographia, where he resolutely and at length catalogues what he explicitly calls the defects and beauties of Wordsworth's poetry. ${ }^{8}$ Moreover, after some initial success, when Henry Crabb Robinson, echoing Hamlet, reports that Coleridge scored 'many palpable and intelligent hits' against Johnson's Preface, it appears that in the next lecture Coleridge has trouble extending to any detail his attack on Johnson's strictures against Shakespeare's lack of clear moral purpose. The sole report we have of this fourteenth lecture in the 1811-12 series comes from Robinson's Diary: 'His continuation of remarks on Johnson's Preface very feeble and unmeaning compared with his last. He had no answer to the general faults ascribed but the complaints of the generality of the imputation.' Finally, when Robinson reports that Coleridge says 'High moral feeling is to be deduced from, tho' not in Shakespeare', this approximates Johnson's statements that 'he seems to write without any moral purpose', but 'From his writings indeed a system of 


\section{ROMANTICISM}

social duty may be selected,' and 'from his works may be collected a system of civil and oeconomical prudence' (LL, I, p. 116; pp. 71, 62; emphases added).

Coleridge's extreme response to Johnson's concern with the moral nature of the plays may be gleaned from what he wrote years later in a copy of his son Hartley's Worthies of Yorkshire and Lancashire: 'I could wish to have preserved a long and spirited conclusion of one of my courses of Lectures on the Sycophancy and cynic Assestation of $D^{r}$ Johnson, both as a Critic, a Moralist ( $\&$ most strongly as a critico-moral Biographer) to the plebeian envy of the patrician Mediocres, and the Reading Public' (CM, II, pp. 75-76, quoted in LL, I, p. 394; cf. I, pp. 117-18 and n.13). Johnson and Pope do intimate that Shakespeare wrote for all levels of his audience, including the vulgar or low. Shakespeare may be gross, protests Coleridge, but not vicious (LL, I, p. 117). Yet, however disturbed Johnson may be by 'impurities' in Shakespeare's language, he never says Shakespeare is vicious. He says of comic characters: 'their jests are commonly gross', then concludes that Shakespeare, among the 'modes of gayety' his age offered, should have chosen 'the best' ( $p .72$ ). Coleridge remarks that Shakespeare's age was coarse in manners and that the characters' language partakes of this, but that Shakespeare himself presents morality in a decent, even model light. Coleridge declares Shakespeare more pure than other writers. Probably with an eye to Johnson's comment that Shakespeare was 'so much more careful to please than to instruct, that he seems to write without any moral purpose', Coleridge counters that Shakespeare 'was a writer of all others the most calculated to make his readers better as well as wiser' (LL, I, pp. 521-22).

Coleridge introduces writers contemporaneous with Shakespeare to indicate how cultured the age could be. And Johnson, while mentioning 'the barbarity of the age', also speaks of its 'stateliness, formality and reserve,' too (pp. 71, 72). But, ironically, Coleridge himself declares a progress in morals, too. Collier reports he said: 'Another cause of false criticism was the greater purity of our morals in the present age which he maintained however villified was in morality superior to the last. Who now would venture to read even a number from the Spectator or the Tatler to his wife or daughters without first examining it to see if there were any improper sentences not fit for the delicacy of female ears?' (LL, 1, p. 191). It is not, then, as some scholars have asserted, that Coleridge's historical view of morals in the Elizabethan age differs from Johnson's. It does not. Nor does his view that morals had progressed and improved. That's substantially the same as Johnson's, too. Rather, Coleridge insists that Shakespeare, while at times imitating the grosser language of the manners of his age, was isolated 
from or rose above its lower morals. The crucial distinction is not historical per se, but simply that Coleridge excuses Shakespeare from any moral laxity or charge of nonchalance in presenting moral feelings. Johnson does not. Coleridge's peroration to his first lecture on Shakespeare and education (1813) hits the high-water mark of his defense:

The writings of Beaumont and Fletcher bear no comparison; the grossest passages of Shakespear were purity to theirs; and it should be remembered that though he might occasionally disgust a sense of delicacy, he never injured the mind; he caused no excitement of passion which he flattered to degrade, never used what was faulty to a faulty purpose; carried on no warfare against virtue, by which wickedness may be made to appear as not wickedness, and where our sympathy was to be entrapped by the misfortunes of vice: with him vice never walked as it were in twilight. He never inverted the order of nature and propriety, like some modern writers, who suppose every magistrate to be a glutton or a drunkard, and every poor man humane and temperate; with him we had no benevolent braziers or sentimental ratcatchers. Nothing was purposely out of place. (LI, I, p. 522)

\section{ACT III. THE UNITIES AND RULES}

For Coleridge, Johnson over-values 'rules of criticism'. Determined to show that Shakespeare's apparent irregularities were but means to a greater end, Coleridge claims that Shakespeare's violation of the unities of time and place, as well as mingling comic with tragic scenes, contribute to larger, organic plans. In Biographia, Coleridge attributes this insight to Lessing: 'It was Lessing who first proved to all thinking men, even to Shakespeare's own countrymen, the true nature of his apparent irregularities.' Yet, as my co-editor of Biographia, W.J. Bate, notes, rather gently, 'This statement is so completely at variance with the facts (the defence and understanding of Shakespeare's "apparent irregularities" are common in eighteenth-century English criticism, especially after 1765, the date of Johnson's Preface) that one can only assume that Coleridge at this moment is nodding or partly thinking of something else while dictating to Morgan' (BL, II, p. 209 and $n .3)$. The only explanation, aside from Coleridge's ignorance, which is doubtful, or his exaggeration, which is possible, is that Coleridge may genuinely believe that previous defences of Shakespeare against the charge of irregularities were propounded for the wrong reasons and failed to appreciate the organic plan of each drama. In a Notebook entry used for his Shakespeare lectures, Coleridge does admit 'one or two exceptions' to this 
critical tendency (LL, I, Pp. 78-9 and nn. 9-12). But that Johnson is one seems unlikely.

Repeatedly, Coleridge returns to the fact that ' $D$ r Johnson has remarked that little or nothing is wanting to render the Othello a regular tragedy but to have opened the play with the arrival of Othello in Cyprus, and to have thrown the preceding Act into the form of narration. Here', says Coleridge, 'then is the place to determine, whether such a change would or would not be an improvement, nay (to throw down the glove with a full challenge) whether or no the Tragedy would by such an arrangement become more regular, i.e. more consonant with the rules dictated by universal reason or the true Common Sense of mankind in its application to the particular case' (LL, II, p. 316). But Johnson does not label this irregularity a fault. From his remarks it may be inferred, true, for he says, 'Had the scene opened in Cyprus, and the preceding incidents been occasionally related, there had been little wanting to a drama of the most exact and scrupulous regularity' (p. 79n). But he does not push the case. In fact, Johnson states in the Preface, 'a play, written with nice observation of critical rules, is to be contemplated as an elaborate curiosity, as the product of superfluous and ostentatious art' (p. 80).

Coleridge sees Pope and others adhering to the unities of time and place as irrevocable rules. In Biographia Coleridge says, ' $\mathrm{M}^{\mathrm{r}}$ Pope was under the common error of his age, an error, far from being sufficiently exploded even at the present day. It consists (as I explained at large, and proved in detail in my public lectures) in mistaking for the essentials of the Greek stage certain rules, which these poets imposed upon themselves, in order to render all the remaining parts of the drama consistent with those, that had been forced upon them by circumstances independent of their will; out of which circumstances the drama itself arose.' Coleridge refers to the presence of the Chorus and the fact of the open stage. But even if we accept the remark about the Greek stage dictating a unity of time and place, the remark about Pope is not true. Pope states in his Preface that to judge Shakespeare 'by Aristotle's rules, is like trying a man by the laws of one country, who acted under those of another' (BL, I, p. 34n and n. 1; see LL, I, p. 226). While some critics did support all the unities in Coleridge's day, even a partial list of previous ones either opposing or overlooking them is impressive: Dryden in his 'Heads of an Answer to Rymer', Farquhar (1702), Pope (1725), Kames (1762), Webb (1762), Johnson, of course (1765), and Lessing (1767-8). While Johnson uses the word 'irregular' to characterize Shakespeare, he speaks of this very irregularity as an 'authority' over and above 'the triumphant language with which a critick exults over the misery of an irregular poet', and states that while Shakespeare may have rejected 
the unities of time and place by 'happy ignorance', he also may have done so 'by design' (pp. 76, 79).

What, then, is Coleridge's point, or is his point in error? In his defence, though he presents his history of criticism askew, throwing himself in a more original light, he is not saying the same thing these critics say. They excuse Shakespeare from the unities of time and place, or question the appeal of those unities outside the development of drama in ancient Greece. But Coleridge states that Shakespeare's drama, of an entirely different order than any other playwright's, is an intentionally interwoven and planned whole whose fabric differs from play to play. The burden of previous critics is often negative, to excuse Shakespeare from rules that, as even Johnson admits, 'may sometimes conduce to pleasure' (p. 80); Coleridge's positive mission is to demolish all vestiges of that authority and to ground Shakespeare's 'consummate judgement ... not only in the general construction, but in all the detail, of his dramas' (BL, I, p. 34n). Yet, Johnson starts down this path, too. Of mingling tragedy and comedy, he says, 'That this is a practice contrary to the rules of criticism will be readily allowed; but there is always an appeal open from criticism to nature'. As for the convergence of detail and broad construction, Johnson notes that the mingled drama 'approaches nearer than either [comedy or tragedy alone] to the appearance of life, by shewing how great machinations and slender designs may promote or obviate one another, and the high and the low cooperate in the general system by unavoidable concatenation.' Among his clearly negative remarks on the unities of time and place Johnson states, 'Such violations of rules merely positive, become the comprehensive genius of Shakespeare. . .' (pp. 67, 79).

Though the reason uncharacteristically escapes the latest editor of Coleridge's lectures, it thus seems clear why, when Coleridge remarks on the heightening of effect in Lear by the mixture of agony with 'the mimicry of the fool', J.P. Collier should copy in his notes a passage from the Preface dismissing the unities (LL, I, p. 212 and n.40). For Johnson the unities are tied to the same putative and theoretical realism that demands an unmingled drama.

As briefly stated in Biographia, Coleridge's principle of organic unity, 'that nothing can permanently please, which does not contain in itself the reason why it is so, and not otherwise' (BL, II, pp. 12-13 and n.), contains two interesting echoes of Johnson, the first from the Preface, that 'Nothing can please many, and please long, but just representations of general nature' (p. 61), the second from Rambler 154, on criticism: 'That which hopes to resist the blast of malignity, and stand firm against the attacks of time, must contain in itself some original principle of growth.' H.J. Jackson even 


\section{ROMANTICISM}

suggests that this kind of unconscious assimilation on Coleridge's part may betray an influence deeper than direct quotation: 'This is in fact a typical pattern in his writings, in which the use of the exact words of another author . . . is a sign of relative "faintness of Impression", and conversely, his changing the words is a sign of deep impression and thorough assimilation' ('Johnson's Milton', pp. 41-45, p. 42 and n.)

\section{ACT IV. DRAMATIC ILLUSION}

Both Johnson and Coleridge agree that adherents to the unities falsely believe them to heighten the reality of the performance and to increase its impact on the audience. Discussion of the unities leads to discussion of dramatic illusion. In his third lecture of 1811-12, Coleridge 'attempted to shew that the Unities of time $\&$ place were not essential to the drama, \& that to suppose them necessary was to suppose as evident a falsehood as that the Drama impresses with pleasure only as it is supposed to be reality' (LL, I, p. 227). Because Johnson says no delusion occurs, Coleridge associates him, erroneously, with the view that no illusion occurs at all; and French critics with the view that it's all delusion. And these two views, claims Coleridge, become the same: 'The Subject of Stage-Illusion is so important, and so many practical Errors \& false criticisms may arise, and indeed have risen, either from reasoning on it as actual Delusion - (the strange notion, on which the French Critics built up their Theory, and the French Poets justify the construction of their Tragedies -) or from denying it altogether, (which seems the but $[t]$ of $D^{r}$ Johnson's reasoning and which, as Extremes meet, would lead to the very same Consequences by excluding whatever would not be judged probable by us in <our> coolest state of feeling with all our faculties in even balance) that a short digression will, I hope, be pardoned, if it should serve either to explain or to illustrate the point' (LL, I, p. 135). Ten years later in 1818, Coleridge states: 'I find two extremes in critical decision - The French, which evidently presupposes that a perfect Delusion is to be aimed at - an Opinion which now needs no fresh confutation - The opposite, supported by $\mathrm{D}^{\mathrm{r}}$ Johnson, supposes the auditors throughout as in the full and positive reflective knowledge of the contrary. In evincing the impossibility of Delusion he makes no sufficient allowance for an intermediate State, which we distinguish by the term, Illusion' (LL, II, pp. 265-66). These two extremes are the ones Coleridge says meet. His modern editor reinforces this opinion by quoting, repeatedly, the passage in which Johnson says, 'The truth is, that the spectators are always in their senses, and know, from the first act to the last, that the stage is only a stage, and that the players are only players' (p. 77).

But the section in Johnson is more complex. For Johnson, real delusion 
is just that, out of one's senses - 'extasy,' what we would call psychosis. 'Delusion, if delusion be admitted, has no certain limitation' (p. 77). Johnson's idea of delusion is not at all the same as Coleridge's one of dramatic illusion; thus, his denial of delusion is not a denial of all illusion. While Johnson says, 'It is false, that any representation is mistaken for reality; that any dramatick fable in its materiality was ever credible, or, for a single moment, was ever credited,' the key phrase is 'in its materiality' (p. 76). For, shortly afterward, Johnson interjects, 'It will be asked, how the drama moves, if it is not credited. It is credited with all the credit due to a drama. It is credited, whenever it moves, as a just picture of a real original . . . If there be any fallacy,' - Johnson admits there may be - 'it is not that we fancy the players, but that we fancy ourselves unhappy for a moment' (p. 78). Johnson's statement, 'The truth is, that the spectators are always in their senses, and know from the first act to the last, that the stage is only a stage', he further glosses by stating, 'A play read, affects the mind like a play acted. It is therefore evident, that the action is not supposed to be real' (p. 79). This last statement, and Johnson's earlier one ('It is false, that any representation is mistaken for reality') are both echoed when Coleridge asserts that with regard to any drama, 'The truth is, it is never believed to be real' (LL, I, p. 227). Coleridge remarks on the 'temporary Half-Faith, which the Spectator encourages in himself $\&$ supports by a voluntary contribution on his own part, because he knows that it is at all times in his power to see the thing as it really is' ( $L L, ~ l, ~ p . ~ l v)$. Even when Coleridge imputes to Johnson a belief that the audience is in full and positive reflective knowledge' that no delusion exists, and that he therefore does not admit the possibility of illusion, Coleridge's own wording leaves the door open to consider that Johnson might grant the audience a half, negative, or unreflective knowledge of the representation, thus crediting it in some manner. This approximates what Johnson does say: 'We fancy ourselves unhappy for a moment'. Is it too much to infer that in this activity we suspend our disbelief and believe, or credit, the drama?

Since Johnson and Coleridge both reject the unities of time and place on which the most rigid theories of the reality of the drama and its effect on the audience are based; since they both support unity of action, or what Coleridge calls the unity of interest; and since they both affirm that the theater is not itself real but is credited in a special way, it should be no surprise that Johnson and Coleridge are closer together in their sense of dramatic illusion and its effect on the audience than often supposed, certainly closer that Coleridge implies.

Yet if Coleridge does not mention possible predecessors in Trapp, Priestley, Adam Smith, Erasmus Darwin, and August Schlegel (LL, I, pp. lv, lvii), ${ }^{10}$ 


\section{ROMANTICISM}

and if he plants Johnson too much at one extreme on the scale of delusion, it is not to repeat what Johnson actually said and claim it as his own. Coleridge's sense of dramatic illusion is different. He offers a deeper psychological sense of the process of crediting performed by the audience; the effect of a drama is in some fashion like experiencing a dream where our judgement is not operating but is instead suspended because we have brought ourselves to a point where 'We chuse to be deceived.' We do not constantly choose to know, though we could remind ourselves, that the stage is only a stage: we suspend this knowledge voluntarily, even though it is in our power to recapture it. At this point of suspension, 'Images have a negative reality' (LL, II, p. 266). This leads to Coleridge's formulation: 'that willing suspension of disbelief for the moment, that constitutes poetic faith' (BL, II, p. 6 and n). This is not the same as Johnson's observations, one of which he aims directly at how we feel: 'If there be any fallacy, it is not that we fancy the players, but that we fancy ourselves unhappy for a moment' (p. 78). Coleridge echoes this temporal aspect of dramatic effect when he says that our 'willing suspension of disbelief' occurs 'for the moment'. In Biographia, Coleridge returns to 'That illusion, contradistinguished from delusion, that negative faith, which simply permits the images presented to work by their own force, without either denial or affirmation of their real existence by the judgment' (BL, II, p. 134). Despite Keats's disclaimer about Coleridge's own rather unShakespearean intellect in his famous letter recounting their conversation on Hampstead Heath, I wonder if this passage helped to prompt Keats's speculation on 'negative capability'. Keats wrote that letter four months after the appearance of Coleridge's Biographia and, like Coleridge, associates negative faith or negative capability first and foremost with Shakespeare.

\section{ACT V. THE COURSE OF CRITICISM}

R.A. Foakes, M.M. Badawi, J.A. Appleyard, H.S. Robinson, Alfred Harbage, and to a certain degree M.H. Abrams stress the originality and new emphases of romantic and especially of Coleridge's Shakespearean criticism. But R.W. Babcock, however mechanically he chronicles eighteenth-century criticism, knows it well and sees in it a clear forerunner of romantic and Coleridgean interests, as does Augustus Ralli. Coleridge scholars who dip with ease into the eighteenth century, such as H.J. and J.R. de J. Jackson and John Beer, offer balanced and judicious commentary. ${ }^{11}$ Other scholars who have read and written extensively on both sides of traditional lines separating periods, among them W.J. Bate, Frederick Burwick, Leo Damrosch, and Richard Harter Fogle, also produce discriminating judgments. Thus, in comparing eighteenth-century to romantic Shakespearean criticism, and 
Johnson's Shakespearean criticism to Coleridge's (the more specific comparison has been minimally explored), scholars as a whole have divided quite sharply, reflecting their own interests, training, and specialties. ${ }^{12}$ This may seem unsurprising, but when the subject is our greatest poet and two of our greatest critics, both of whom considered that poet at length, such division and variance in critical estimates transforms into a strong caution against traditional period lines and boundaries. 'It is easy to understand why the connection between Johnson and Coleridge has not invited exploration', remarks H.J. Jackson. 'Historically-minded Johnsonians are naturally not much interested in Coleridge, and Coleridgeans seem to reciprocate by ignoring Johnson' ('Johnson's Milton,' p. 30).

Coleridge, a great critic of Shakespeare, introduces new observations and suggestive subtleties in his vision of the plays as organic wholes with interconnections of character, imagery, plot, and moral sense. His best comments on passages and characters - and his psychological insights - are often unsurpassed. His sense of Shakespeare's humanity and artistry, of imaginative power, profound intellect, and feeling, all fused and expressed both in large design and minute phrasing, is keen.

The fact that Coleridge exaggerates his differences with Johnson - and attributes to the older writer a number of positions Johnson never takes may be a result of that perpetual habit of nearly every critic, including many excellent ones, to clear the ground of the previous generation, to answer its objections, and to object to its cherished premises. The more illustrious the critic, the more ingrained this habit can be, and the less accurate any scholarly measure of the previous generation. It may even be that this attitude is in some respect necessary for all critical achievement. Instances are too numerous to mention all. Aristotle seems to answer Plato's indictments of the poet. Longinus excoriates the lackluster spirit of his own age. Young T.S. Eliot attacks the nineteenth century, including Arnold, though he shares much with him and later, on rare occasions, admits it. Arnold himself turns away from what he considers the overly subjective and emotional verse of romantic excess. Sainte-Beuve criticizes the French Academy of the early 19th century and rejects its definition of a classic. Later, regarding Racine and criticism in general, Roland Barthes attacks Gustave Lanson, whose history of French literature was standard. T.E. Hulme and Irving Babbitt rail against the easy 'wet' side of romanticism. Hulme calls it 'spilt religion'. A generation of theorists decry the 'hegemony' of the New Criticism. Harold Bloom has seemed at times to clear away all critical schools, each as somehow inadequate (indeed, any one school taken by itself is), and has built a theory of poetry - and, by extension, of criticism propounded in The Anxiety of Influence (1973), an idea similar to one 
W.J. Bate broached in 1965, when Bate published the germ of his Burden of the Past (1970) as an article in Earl Wasserman's collection Aspects of the Eighteenth Century. Both Bate and Bloom concentrate on the period in English letters spanned by the lives of Johnson and Coleridge.

To oversimplify or misrepresent those critics being dislodged or replaced is so tempting that few have been able to resist it; often, the greater a succeeding critic is, the more urgent, ingenious, and slanted - rather than scrupulous - is the account given of earlier ones. This is one reason we retain a distinction between the roles of scholar and critic. Yet many scholars indulge in this clearing of the ground, too, often using stark labels, periods, and narrowed specialties, finally imagining one critic, school, or method rising in triumph over another grown outmoded and useless. Even Johnson's work would lead us to believe that he was the first, if not among the first, to champion Shakespeare against the unities of time and place and to defend him against the learned, frequently unquestioned rules that forbade the mingling of comedy and tragedy. The truth is that Sidney, Dryden, Farquhar, Pope, Kames, Webb, and others had done much the same, though less thoroughly, and often in less eloquent language.

In many reevaluations, as in the Shakespearean criticism Coleridge directly pits against Johnson's, two basic forces are at work. The first includes: a knowledgeable recognition and characterization of a movement, or of a writer or writers in the past; a keen sense of what criticism has gone before; a grasp not necessarily encyclopaedic and often without pretense to objectivity, but almost always felt deeply, perhaps deeply objected to, and, above all, a grasp firm enough to see past criticism as a powerful presence to be reckoned with, fought against perhaps, or both loved and hated, but, whatever else, not to be regarded as a zone of apathy or ignorance. (The opposite of love, remarks Johnson, is not hate but indifference.) The second force involves a refusal to comply with the direction that the present time seems to be taking under the influence of past criticism or of a dominant literary tradition. Such dissatisfaction or revolt is most fiercely directed against the immediate past, accompanied by a feeling that the course of literary production has somehow dried up, gone wrong, fallen into the hands of rigid theorists or positivists, become too aesthetic or too historical or too sensationalist - the phrases and reasons are legion, but the force is essentially the same - a drive away from the most recent manifestations of tradition and criticism as they have come to be viewed. Wordsworth's Preface to Lyrical Ballads exemplifies these two forces. In English and American literature, the transitions from classic to romantic, from the eighteenth century to the early nineteenth, and later from a romantic nineteenth to a modernist twentieth century, 
witness particularly sharp cusps where these two forces exert their pressure.

Coleridge's audiences still regarded Johnson's and other eighteenthcentury views as standard. The work of Maurice Morgann, George Whatley, Walter Whiter and others, let alone Lamb's and Hazlitt's, were not yet well known. In the middle of what we now regard as the romantic period, the accepted accounts and common editions of Shakespeare came from a generation or two earlier. John Thelwall gave a lecture series on Johnson and Shakespeare as late as 1817-18. Before leaving our particular case, we should recall, too, that Coleridge never published any of his lectures and never prepared them for publication; indeed, only a fraction of material now identified as his Shakespearean criticism did he ever present in anything more than private jottings or to a lecture room, where his main, if not sole, purpose was to get money, often for friends in debt (LL, I, p. xxxix).

The transmission and continued dialogue of criticism such as Johnson, Coleridge, and their contemporaries exhibit is so complex, then, that its story rarely, if ever, can be trusted to the active participants. Nor is it easy now to grasp it as objective history, for interest will nearly always be engaged, even over long stretches of time, unless ulterior motives are suppressed and allegiances to current methods, training, and specializations are put at hazard or negated entirely. This requires an almost superhuman openness and suggests why Johnson considered long durations of time and the collective judgment of generations of common readers superior to the pronouncements of learned critics. We are dealing, after all, with 'works not raised upon principles demonstrative and scientifick, but appealing wholly to observation and experience' (p. 59). It must be admitted that Johnson is, with regard to his predecessors, more honest than Coleridge; but as a critic of Shakespeare it is doubtful that he is more brilliant. $\mathbb{R}$

Department of English and American Literature and Language Harvard University

1. Lectures 1808-1819 On Literature, ed. by R.A. Foakes, 2 vols (Princeton and London: Princeton University Press and Routledge \& Kegan Paul, 1987), I, p. 138 and n.44; fifth title in The Collected Works of Samuel Taylor Coleridge, hereafter cited as LL. In 1996, a five-act oral version of this article was delivered, with successive revisions, to the Johnson Society of the Central Region at Milwaukee, the Coleridge conference at Nether Stowey, and the NASSR conference in Boston. I thank Professors Howard Weinbrot, Nicholas Roe, and Heather Jackson for their assistance in making those presentations and subsequent conversations possible. 


\section{ROMANTICISM}

2. Johnson on Shakespeare, ed. by Arthur Sherbo (New Haven: Yale University Press, 1968) in The Yale Edition of the Works of Samuel Johnson, VII, p. 84; cited hereafter by page number only.

3. Biographia Literaria, ed. by James Engell and W. Jackson Bate, 2 vols (Princeton and London: Princeton University Press and Routledge \& Kegan Paul, 1983), II, pp. 26-7; seventh title in The Collected Works, cited hereafter as BL.

4. Marginalia in Coleridge's copy of The Dramatic Works of William Shakespeare, ed. by Sarnuel Ayscough, 2 vols (1807), associated with Highgate and the lecture series of 1818-19 and now located in the British Museum; to appear as COPY D under 'Shakespeare' in Marginalia, ed. by H.J. Jackson, George Whalley, et al., 5 vols; twelfth title in The Collected Works, cited hereafter as $C M$. I thank H.J. Jackson for permission to view the $C M$ typescript prior to publication. Many studies examine Coleridge's idea of organic wholeness in Shakespeare. James Benziger, 'Organic Unity: Leibniz to Coleridge', PMLA 66, 2 (March 1951), pp. 24 48, draws on the extensive intellectual milieu familiar to Coleridge and relates it to his Shakespearean criticism.

5. For Johnson's insistence that the best authors conquer boredom and compel the reader to read on, see James Engell, 'Johnson on Novelty and Originality', Modern Philology, 75 (February 1978), pp. 273-79.

6. Marginalia in Coleridge's copy of The Works of Shakespeare, ed. by Lewis Theobald, 8 vols (1773), associated with J.J. Morgan and the lectures of 1808-12 and now located in the British Museum; to appear as COPY A under 'Shakespeare' in CM.

7. Gwynne Evans, one of Shakespeare's most eminent modern editors, mentioned to me his opinion that Coleridge ventures only one purely negative criticism of Shakespeare: he objects to Isabella's conduct and the Duke's marriage to her in Measure for Measure. The objection squares with Johnson's accusation that Shakespeare 'sacrifices virtue to convenience' (p. 71). Collier reports that Coleridge called the play the "least agreeable" of Shakespeare's dramas' (LL, II, p. 245).

8. See H.J. Jackson, 'Johnson's Milton and Coleridge's Wordsworth', Studies in Romanticism, 28 (Spring 1989), pp. 29-47. This perceptive article makes astue remarks on Johnson and Coleridge (pp. 30-35) and cites studies that have occasionally yoked the two writers (p. 30 n.2), none of which addresses Shakespeare centrally. The final section of the present article considers the difficulty of exploring the connection between Johnson and Coleridge, an exploration hampered by specialized literary training and the periodization of criticism.

9. Henry Crabb Robinson on Books and Their Writers, ed. by Edith J. Morley, 3 vols (1938), I, p. 57, quoted in LL, 1, pp. 394, 396.

10. For background, see J.R. de J. Jackson, 'Coleridge on Dramatic Illusion and Spectacle in the Performance of Shakespeare's Plays', Modern Philology, 62 (1964-65), pp. 13-21. Foakes addresses the wealth of material on stage illusion available to Coleridge ( $L L, I, p p$. lv-lix). On conjunctions of poetry, truth, (stage) illusion, dream, and fiction in Kames, Blair, Trapp, and Campbell, see James Engell, Forming the Critical Mind, Dryden to Coleridge (Cambridge, Mass: Harvard University Press, 1989), p. 206. Subsequently, a relevant and comprehensive treatment of stage illusion is Frederick Burwick, Illusion and the Drama: Critical Theory of the Enlightenment and Romantic Era (University Park: Pennsylvania State University Press, 1991). Burwick sees Johnson as a sceptic with regard to illusion (pp. 27-31) and notes that Johnson would not accept Kames's idea of illusion as similar to a dream (p. 31), an idea Coleridge develops. Burwick relates Coleridge's views to those of Richard Payne Knight and August Schlegel (pp. 191-229). 
11. See notes 8 and 10; also, John Beer, 'Coleridge, Wordsworth and Johnson,' English Language and Literature, 33 (1987), pp. 25-42, cited by H.J. Jackson.

12. Without producing a bibliography of Coleridge as a critic, or of works that explore the relations of eighteenth-century to romantic criticism, a germane list, in addition to those noted above, may be cited: J.A. Appleyard, Coleridge's Philosophy of Literature: the Development of a Concept of Poetry 1791-1819 (Cambridge, Mass: Harvard University Press, 1965); Robert W. Babcock, The Genesis of Shakespeare Idolatry 1766-1799, A Study in English Criticism of the Late Eighteenth Century (New York: Russell and Russell, 1964 [1931]); Muhammad Mustafa Badawi, Coleridge, Critic of Shakespeare (Cambridge: Cambridge University Press, 1973); Leopold Damrosch, Jr., The Uses of Johnson's Criticism (Charlottesville: University Press of Virginia, 1976); Augustus Ralli, A History of Shakespearian Criticism (London: H. Milford for Oxford University Press, 1932). 